\title{
CONFERENCE PARTICIPANTS
}

1999

\section{Keynote Speaker}

Luis M. Proenza, President

University of Akron

\section{lowa State University}

Charlotte R. Bronson, Professor of Plant Pathology

Bruce Harmon, Deputy Director of the Ames Laboratory

Distinguished Professor of Physics

P. B. Swan, Vice Provost for Research \& Advanced Studies

\section{Kansas State University}

Bikram S. Gill, Director of the Wheat Genetics Resource Center University Distinguished Professor of Plant Pathology

Marc A. Johnson, Dean of Agriculture

Director, Agricultural Experiment Station \& Cooperative Extension Service

R. W. Trewyn, Vice Provost for Research \& Dean of the Graduate School President, KSU Research Foundation

\section{University of Missouri - Columbia}

Andrew J. Blanchard, Director of Research, College of Engineering

Professor of Electrical Engineering

Jack O. Burns, Vice Provost for Research

Roger A. Sunde, Professor \& Chair of Nutritional Sciences

Cluster Leader, Food for the $21^{\text {st }}$ Century

Richard L. Wallace, Chancellor

\section{University of Nebraska}

Thomas Rosenquist, Director of Research, Medical Center in Omaha Chair, Cell Biology \& Anatomy

\section{Other Participants}

Keith Yehle

Legislative Assistant to Senator Pat Roberts

Washington, D.C.
Bob Woody

Shook, Hardy \& Bacon

Washington, D.C. 


\section{University of Kansas}

Robert E. Barnhill, Vice Chancellor for Research \& Public Service

President of CRINC

Sally Frost Mason, Dean of Liberal Arts and Sciences

Professor of Molecular Biosciences

Robert Hemenway, Chancellor

Roberta Johnson, Director of the Hall Center for Humanities

Ted Kuwana, EPSCOR Director \& Regents Distinguished Professor of Chemistry

Kathleen McKluskey-Fawcett, Associate Provost

Mabel Rice, Director, Merrill Advanced Studies Center

University Distinguished Professor of Speech-Language-Hearing

James Roberts, Associate Vice Chancellor for Research \& Public Service

Dick Schiefelbusch, Director Emeritus, Life Span Institute

Steve Schroeder, Director, Life Span Institute

David E. Shulenburger, Provost

Don Steeples, McGee Distinguished Professor of Geophysics

Marilyn Stokstad, Judith Harris Murphy Distinguished Professor of Art History

George S. Wilson, Higuchi Professor of Chemistry \& Pharmaceutical Chemistry

\section{University of Kansas Medical Center}

Charles DeCarli, Director, Alzheimer's Center \& Professor of Neurology

Don Hagen, Executive Vice Chancellor

K. Michael Welch, M.D., Vice Chancellor for Research

\section{Kansas Board of Regents}

Kim A. Wilcox, Executive Director 